\title{
Jeeps, Communists, and Quonset Huts: World War II Surplus Disposal in the Territory of Hawai'i
}

\author{
GWEN SINCLAIR
}

In THE WANING DAYS of World War II, the Honolulu Advertiser published a prescient article by a reporter named Gerry Burtnett about military surplus disposal:

The disposal of surplus property in Hawaii is going to be one of the biggest stories of the last days of the war and the postwar period. It may be a rather unpleasant story, from present indications. ${ }^{1}$

Disposal of war surplus in Hawai'i was a big story, judging from the hundreds of newspaper articles about it published between 1945 and $195^{\circ}$. As soldiers, sailors, and marines returned home and life in the Territory began to be shaped by peacetime concerns, surplus disposal became an important industry in the Territory of Hawai'i and in the nation as a whole. The disposal of surplus property captured the attention not only of the surplus-consuming public, but also of Congressional investigating committees. This paper will examine the effects of surplus disposal, why surplus held people's attention for so long, and the major events and key people involved with surplus disposal in the Territory of Hawai'i.

Gwen Sinclair is a librarian and Head of the Government Documents E Maps Department at the University of Hawai' $i$ at Mānoa Library. Her publications and research interests range from government secrecy to presidential executive orders and proclamations relating to federal property in Hawai $i$.

The Hawaiian Journal of History, vol. $5^{\mathrm{o}}$ (2016) 
Long before the end of World War II, officials in Washington, D.C. recognized that disposal of quantities of salvage and surplus government property, primarily by the armed forces, would be required. As a staging area for bases in the Pacific, the Territory of Hawai' $i$ held millions of tons of building materials, equipment, clothing, foodanything and everything needed to fight the war-at the close of hostilities in September 1945 .

To facilitate the orderly disposal of surplus, the U.S. Congress passed the Surplus Property Act in 1944, which established the Surplus Property Board and directed it to issue regulations for the disposition of surplus personal and real property. ${ }^{2}$ The regulations prioritized recipients for the disposition of surplus property as follows:

1. Federal government

2. State and local governments

3. Veterans (those who were certified as having served in WWII)

4. Certified non-profit institutions

5. Small dealers

6. Wholesalers

7. Large dealers

8. General public ${ }^{3}$

Congress gave a high priority to veterans, who were anticipated to farm or start small businesses with the help of surplus goods. Veterans could also obtain surplus for their personal use, so they were wellpositioned to acquire many of the thousands of vehicles and other items declared surplus.

\section{The Beginning of Surplus Disposal in Hawai'i}

The organization of the mechanics of surplus disposal took a long time, so surplus disposal did not really begin in earnest until late 1945. On the U.S. Mainland, several agencies handled surplus disposal in rapid succession, and eventually the War Assets Administration (WAA) became the principal agency handling disposition of surplus property. However, in Alaska, Hawai' $i$, Puerto Rico, and the U.S. Virgin Islands, the Surplus Property Office (SPO) of the Department of the Interior was initially charged with the disposal of everything except aircraft and vessels. In September 1945, Crawford Sloan, assistant director of SPO, opened an office located at 'Iolani Palace in 
Honolulu. Advertisements were placed for office assistants, engineers, appraisers, inspectors, and investigators to staff the office, which eventually employed at least 228 people. ${ }^{4}$

Col. William B. Cobb was hired to head the Honolulu office of SPO in December 1945. Like many people who worked in surplus disposal, he had just been discharged from the Army. Formerly a lawyer and Wyoming legislator, he had served as assistant chief of staff for General Delos Emmons (commanding general of the Army's Hawaiian Department and military governor from 1941-1943) during the war. ${ }^{5}$ One might wonder how Cobb's background qualified him to lead surplus disposal in the Territory. Cobb did not have any direct experience with surplus disposal, and this may have contributed to some of the difficulties he encountered, which will be discussed later. It is conceivable that his past experience with the Army in Hawai' $i$ was seen as an advantage. Furthermore, there may have been a desire to hire an outsider who was not previously associated with surplus disposal and therefore not tainted by complaints that surplus sales were moving too slowly.

\section{Congress Investigates}

Cobb faced a daunting task. The War Department and Navy had not yet determined how much material would be declared excess to their needs because the size and distribution of the peacetime armed forces had not yet been determined. At the same time, civilians who had been deprived of many consumer goods during the war saw the mountains of material stockpiled at military bases, warehouses, and depots and demanded immediate access. Many complaints were received by members of Congress, resulting in the creation of special committees to investigate war industries. Now that the war was over, these committees turned their attention to investigation of the massive disposal bottlenecks in the U.S. and in overseas theatres.

The Senate Special Committee Investigating the National Defense Program held a hearing in Washington, D.C. in November 1945 at which Sloan testified that he had heard stories about or personally observed numerous instances of the destruction of usable surplus property by the Army and Navy while he was in Honolulu. Interestingly, Sloan testified that he took reporters from both the Honolulu Advertiser and the Honolulu Star-Bulletin with him on some of his visits 
to salvage yards. Apparently, Sloan hoped that the reporters would shine a spotlight on the destruction of automobiles, construction material, and other items that, in his opinion, could be sold as surplus. However, the Advertiser decided that the story was too "hot" and elected not to publish it. Sloan claimed that the paper's reluctance was due to the publisher's friendship with General Richardson, who was the commanding general of the armed forces in the middle Pacific and military governor of Hawai'i. The Star-Bulletin does not appear to have reported a story about a visit to the Army Corps of Engineers Reclamation Yard, where Sloan and a reporter observed prisoners of war cutting up new roofing material to level the yard. ${ }^{6}$

Members of the special committee undertook a world tour to visit surplus disposal operations and question both civilian and military officials about the progress of disposal and alleged mishandling of surplus property. Between visits to California and the Marshall Islands, a subset of committee members, Senators Tunnell, Mitchell, and Knowland, accompanied by George Meader, the committee's counsel, conducted hearings in Honolulu from December 31, 1945 through January 2, 1946. Their questioning mainly focused on the alleged destruction of perfectly good vehicles by the Army. Two SPO employees, George J. Ryan and Tommy Miller, had visited a salvage depot at Schofield Barracks. They claimed to have observed vehicles with low mileage being cut apart and scrapped. Ryan subsequently wrote a confidential report containing many allegations of misconduct on the part of the armed services. ${ }^{7}$ Army officials vehemently denied these charges and asserted that vehicles were scrapped because they were too dangerous to drive and could not be economically repaired. ${ }^{8}$

Although most of the committee's attention was directed at the disposal of surplus WW II material, the existence of surplus remaining from previous conflicts did not go unnoticed. For example, a stockpile of saddles at Schofield Barracks that dated back to the SpanishAmerican War of 1898 caught the attention of Meader, the committee's legal counsel. ${ }^{9}$

\section{What Was for Sale?}

What did the Army and Navy ultimately decide to get rid of? When one thinks of military surplus, one is likely to imagine items like jeeps, 
clothing, weapons, tents, and the like. There was certainly an abundance of all shapes and sizes of vehicles, from two-and-a-half ton trucks to jeeps to passenger cars. Even bicycles used at Pearl Harbor were declared surplus. Aside from Army boots, clothing for the full range of Army and Navy personnel was released for sale-jackets, pants, pajamas, WAAC and WAVE skirts and blouses, nurse's uniforms, and of course underwear. Food, medications, medical supplies, hospital beds and sheets, dishes, furniture, and tents were released by the hundreds of thousands.

Both the Army Corps of Engineers and the Navy Construction Battalion (Seabees) had massive quantities of construction material and equipment, from lumber, roofing, fence posts, and barbed wire to bridge sections, road grading equipment, tractors, generators, and electrical supplies. Wooden frame buildings, Dallas huts, and Quonset huts were dismantled or sold whole. The Signal Corps had typewriters, telephones, switchboards, radios, photographic equipment and supplies, and office supplies. Some of the more unusual surplus items offered for sale in Hawai'i included Army mules, beeswax, spun glass cloth, scale models of ships and airplanes, a horseshoer's kit, cigarettes, pigeon lofts, and a threshing machine.

Naturally, many aircraft and parts were no longer needed after the war, and both the Army and the Navy declared many planes surplus or salvage. Similarly, both the Army and Navy possessed a variety of vessels, from tugs and barges to commercial fishing boats to ships and motor launches that needed to be sold or scrapped. Marine engines were particularly sought-after items. Initially, the Reconstruction Finance Corporation was designated to dispose of aircraft and the Maritime Commission had responsibility for disposal of vessels. Eventually, aircraft and vessels were placed under WAA's jurisdiction.

Not only was personal property being disposed of; real property owned by the federal government or leased by the armed forces was also reviewed and transferred to the Territory or returned to civilian use. There was an urgent need for housing in Hawai' $i$ and throughout the U.S. both during and after the war. Lumber and construction equipment and supplies were almost as eagerly sought after as automobiles. The Army released several former camp sites for emergency housing, including a camp near Robert Louis Stevenson School, the Army cantonment at John Rodgers Airport, a camp adjacent to the Territorial Hospital in Kane'ohe, a camp in Waipi'o, and a camp at 
Atkinson Park. ${ }^{10}$ The former Marine base in Waimea (Kamuela), called Tarawa, was dismantled and its 400 buildings, including 100 Quonset huts, were offered for sale. ${ }^{11}$ Not all buildings were sold, however; some were reused by the armed services. For instance, a Quonset hut village on Kamehameha Highway once used to house WAVES was redeployed for Navy dependent housing. ${ }^{12}$

\section{Who Purchased Surplus, and What Did They Buy?}

Army jeeps, which could travel over many types of terrain and were easy to repair, were perennially popular. Kona coffee farmers began to purchase jeeps to replace mules on coffee farms, a move that transformed coffee harvesting. ${ }^{13}$

One of the first sales of surplus took place in September 1945 and featured aircraft auctioned by the Resolution Finance Corporation, the government agency that initially handled surplus aircraft. With the resumption of tourist travel following the war, several airlines sprang up or expanded their services. Some, like Rainbow Airlines, employed surplus C-47 aircraft to conduct inter-island flights within the Territory. ${ }^{14}$

The Territorial government and counties were major recipients of surplus personal property acquired through purchase or donated by WAA or the armed services. Items acquired by local government entities included fire engines, bed linens, tractors, bulldozers, automobile parts, marine equipment, office furniture, paint, toiletries, diesel engines, cafeteria benches, water pumps, refrigerators, flagstaffs, manila rope, fertilizer, and kitchen equipment.

Surplus real property included thousands of buildings that had been used for everything from guard shacks to administration buildings, barracks, mess halls, theaters, hospital wards, and warehouses. Even an Army chapel located at Schofield Barracks ended up on the auction block. ${ }^{15}$ Many buildings were transferred to the Territorial government for uses such as school buildings, day care centers, cargo storage, machine shops, plant nurseries, and administration facilities. The Hawai'i Housing Authority purchased 1, ooo Navy Quonset huts in early 1946 to house veterans and "distressed service families." ${ }^{16}$ The Territorial Department of Public Works, Hawai'i Housing Authority, Board of Agriculture and Forestry, and Maui County were given por- 
tions of the former Kahului Naval Air Station in early 1948. ${ }^{17}$ Several Navy ward buildings at the Waipi'o hospital were transferred to the University of Hawai'i in July 1948 to be converted into housing for students and faculty who were veterans of World War II. ${ }^{18}$ Buildings from $\mathrm{Pu}$ 'unene air field on Maui were purchased by the Territory in October 1948 to be used at Kalaupapa and at schools on Moloka'i, Lana'i, and Maui. ${ }^{19}$

The Territorial government was not the only purchaser of buildings. Quonset huts purchased by individuals became restaurants, homes, and shops. A 1946 newspaper advertisement by M. P. Woolley Contractors Ltd. offered Quonset homes with a selection of floor plans. Famed Honolulu architect Vladimir Ossipoff designed a house for the Harold S. Burr family of Kane'ohe out of two Quonset huts. ${ }^{20}$ Not everyone wanted to see surplus military buildings in their neighborhoods, however. Community members joined forces with the Outdoor Circle, a local non-profit organization that promoted beautification, to oppose the invasion of Quonset huts. Eventually, the Honolulu Board of Supervisors enacted legislation to prohibit construction of the buildings in urban residential neighborhoods, and they were restricted to rural and industrial areas. ${ }^{21}$

The April 1, 1946 tsunami caused the normal order of surplus disposal to be suspended and occasioned the purchase of lumber and other building materials by the Territorial government to aid in rebuilding damaged homes and other structures. Surplus set aside for tsunami relief had mostly been distributed by the time buildings at the $\mathrm{Pu}^{\prime} \mathrm{u} \mathrm{Ki}^{\prime} \mathrm{i}$ Training Camp near Kahuku were released for sale to tsunami victims in June $1946 .^{22}$

While surplus was a boon to many, news articles also pointed out that purchasing surplus had its pitfalls. Buck Buchwach, a writer for the Honolulu Advertiser, described his own experiences with the purchase of a surplus jeep that he named "Buckety Buck." He warned that jeep buyers might face repair bills of several hundred dollars to get a jeep in condition to pass inspection. In addition, spare parts were difficult to obtain. ${ }^{23}$ A. A. Smyser wrote a series of articles in the Honolulu Star-Bulletin about surplus buyers in November 1947. He shared a story of two veterans who purchased a quantity of cups. However, the buyer they had lined up backed out of the deal, leaving the veterans without enough cash to cover their investment. ${ }^{24}$ 


\section{Surplus Dealers}

A number of companies and businesses sprang up or expanded their existing activities to purchase and resell surplus items in the Territory. A review of telephone directories, city directories, and newspaper advertisements provides at least a partial listing of surplus dealers on O'ahu:
AJ Abbot
Island Surplus Supply
A L Kilgo Co.
Island Fish \& Salvage Co.
A R Nylen
Kauai Auto \& Machine Shop Ltd.
Acme Surplus Sales
A M McConnell Enterprises
L \& F Construction \& Equipment Dealers
Ben Seelig \& Co.
Lesser's Equipment Co.
Borck Surplus Store
M. Lerman Co.
Commercial Motors
M. P. Woolley Contractors Ltd.
Commercial Sales Co.
Moanalua Exchange Ltd.
Crossroads Sales \& Service
Pacific Suppliers Ltd.
David R. Heath Co.
Richard Wong
Dean Kepcha
Romanne Co.
Engineering Equipment Co.
Sam's Surplus
Frank F. Fasi Supply Co.
Sorrell \& Son
George S. Imamoto, Contractor
Stewarts' Alakea Toy Shop
Harry A. Hart Co.
Harry B. Kronick \& Co.
Surplus Center
Hawaiian Salvage Co., Ltd.
Surplus Sales Store, Ltd./Silverman's
Industrial Corporation, Ltd.
Tajiri Lumber \& Supply Co.
Wahiawa Surplus
Industrial Development
War Surplus Store Trading Center
Inter-Island Metal \& Salvage Co.
William J. Kimi \& Co.

The number of surplus dealers listed in the $\mathrm{O}^{\prime}$ ahu telephone directory increased from two in $194^{6}$ to fifteen in $195^{\circ}$. Not all businesses that dealt in surplus were listed under the category "Surplus Materials" in the directories, however, so it is possible that there were many more dealers.

\section{United Nations Relief and Rehabilitation Administration}

In addition to the federal and local governments, veterans, and surplus dealers, the United Nations Relief and Rehabilitation Admin- 
istration (UNRRA) became a significant purchaser of U.S. surplus around the world and was the largest single purchaser of surplus in the Territory of Hawai ‘i. Established in 1943, UNRRA's mission was to assist war-torn countries by helping displaced persons, providing food and medical aid, and helping countries to rebuild their economies through the rehabilitation of agriculture and industry. ${ }^{25}$

An initial expedition to Hawai' $i$ was undertaken in January 1946 by Paul Kepple, Associate Director of Surplus Property Operations for UNRRA, and Harry Bolman of the SPO to investigate the potential for purchasing Hawai'i surplus to send to China. Their assessment was that 60 to 70 percent of China's needs could be met using Hawai' $i$ surplus. At the same time, UNRRA set aside two million dollars for procurement in the Territory. ${ }^{26}$ Oddly, most of the money UNRRA used to purchase U.S. surplus (about 73 percent) came from the U.S. government. The arrangement for UNRRA to purchase military surplus was advantageous to the U.S. because UNRRA used the U.S.'s contributions to purchase U.S. surplus, which amounted to a "bookkeeping transfer" rather than a release of new funds. The advantage to UNRRA was that it could immediately acquire needed goods without having to wait for new production. Furthermore, prices were low, and goods were already located close to where they were needed. ${ }^{27}$

UNRRA decided to open an office in Honolulu to facilitate inspection and purchase of surplus materials and shipping. Dewey T. Jones, who had previously been Chief, Domestic Surplus Property Section, Procurement Coordination Branch, Bureau of Supply in UNRRA's Washington, D.C. office, was assigned to Honolulu to serve as Area Surplus Procurement Officer. UNRRA was given office space with the SPO at 'Iolani Palace. All of the employees who worked for UNRRA in Honolulu were on the SPO payroll except for Jones. The SPO employees assigned to UNRRA were Harry Bolman, Chief of UNRRA Section; Evelyn Wong, his secretary (tragically, she died of typhus in 1947 after being sent to Hilo to assist with a surplus sale for WAA); Ruth Tomioka, Jones' secretary; Ah Ha Lee, clerk/typist; and Leonard Fong, assistant to Bolman. ${ }^{28}$

Initially, UNRRA was included in the first priority group for surplus purchases, at the same level as the federal government. However, when the priorities were revised in 1946, UNRRA slipped to the fifth priority, and its surplus acquisitions in Hawai'i declined. Most of the 
surplus purchased by UNRRA in the Territory went to China in support of four programs: agricultural rehabilitation, industrial rehabilitation, food, and medical supplies. Hawai'i surplus (mostly tractors and food) was also sent to Yugoslavia, Greece, Italy, Poland, Albania, Czechoslovakia, and Ukraine. ${ }^{29}$

The first purchase of Hawai'i surplus made by UNRRA in 1945, prior to the opening of its Honolulu office, included tractors, Army mules, diesel engines, food, and medical supplies for China. ${ }^{30}$ Readers may wonder why the Army still had mules in 1945. The Hawaiian Pack Train, part of the $24^{\text {th }}$ Infantry Division, was used to carry supplies to remote outposts in the Ko olau mountains. ${ }^{31}$ It was disbanded in 1944, but the mules were retained and the Army began training them to assist with amphibious operations in the Pacific. ${ }^{32}$ They were one of the first items to be declared surplus by the Army.

Buck Buchwach, a reporter for the Honolulu Advertiser, wrote a tongue-in-cheek article about the UNRRA mules, "as told by an ex-

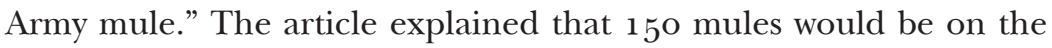
deck of the DePauw Victory, while the remainder were kept in stalls below. The mules were accompanied by an UNRRA veterinarian and 55 GIs from the 298th Quartermaster Service Co. who served as stallboys. Among the GIs were ten veteran muleskinners, headed by Honolulu resident Capt. Clifton S. Weaver and including local men Pfc. John Jay, Pfc. Thomas Chee, Pvt. Joe Himan, Pfc. Albert Ching, Pfc. Edward Lopez, and Cpl. David Kalawaia. ${ }^{33}$

Another significant purchase by UNRRA involved 14 C-46 airplanes that were procured for the Chinese National Relief and Rehabilitation Administration (the China operation of UNRRA) to transport goods within China. The planes were later used as part of the start-up fleet of China Air Transport, an air service begun by General Claire Chennault that was later operated by the Central Intelligence Agency. ${ }^{34}$

\section{SPO PERSONNEL OF NOTE}

Of all the people who worked for SPO in Honolulu, Cobb was the one who shaped it the most. When WAA took over SPO's operations in February 1947, Cobb was passed over for the position of WAA regional director. SPO employees were so upset at this turn of events 
that they sent a cable to the head of WAA in Washington in which they protested the "ouster" of Cobb and claimed that delays in disposing of surplus property were attributable to "meddling” from SPO's associate director in Washington, E. Boykin Hartley. The cable further asserted that Hartley was prejudiced against Cobb and had impugned the reputation of the Honolulu SPO office. The cable also protested a report sent by WAA to the Honolulu office that implied that SPO employees were dishonest or disloyal. The SPO staffers even visited Governor Stainback to request his assistance in the matter. ${ }^{35}$ Among the signers of the cable to WAA was future Senator Masayuki "Spark" Matsunaga. Matsunaga, a veteran who had served in the looth Infantry Battalion, was hired to certify veterans so that they could purchase surplus as priority buyers. Upon leaving the Army, he had served as a separation counselor prior to joining SPO in December $1945 \cdot{ }^{36}$

John W. Palmer, Jr., who was appointed regional director, offered Cobb a position as associate director, which Cobb declined. In his resignation, Cobb stated that Washington had issued "ridiculous and absurd directives" since October 1946 (not coincidentally the date when Hartley began working at WAA). Cobb blamed the requirement that all pricing, advertising, and awards to purchasers be approved by Washington for standing in the way of the Honolulu office's performance. ${ }^{37}$

\section{Complaints, Complaints, Complaints}

Many complaints arose from the regulations and policies that determined priorities, pricing, and geographic distribution of surplus material. There was an urgent desire to quickly determine local needs in order to release material not needed in the Territory so that it could be shipped to the Mainland. To this end, in March 1946 Secretary of the Interior Krug ordered a territorial advisory committee to conduct a survey of the Territory's needs. Once the local demand had been determined, the remainder was to be sent to the Mainland. ${ }^{38}$ Honolulu surplus dealer Harry Kronick, general manager of Industrial Corp., complained to Governor Stainback that Krug's order was discriminatory and requested that Stainback do what he could to intercede. He argued that shipment to the Mainland was wasteful, that Mainland buyers were already in Hawai'i to buy things, and 
Hawai'i deserved to have its own WAA office just as regions on the Mainland did. ${ }^{39}$

Not only were there complaints about Hawai'i surplus going to the Mainland, but there also appears to have been a coordinated national protest against Hawai'i surplus being supplied to "communist-leaning" countries. One dealer wrote to Senator Joseph McCarthy of Wisconsin alleging that 6o percent of Hawai' $i$ surplus was going to Yugoslavia and Korea. McCarthy responded that he had checked with WAA and confirmed that no surplus was going to Yugoslavia and that surplus requested by General MacArthur was being shipped to Korea to support U.S. forces there. Meanwhile, a group of dealers, including Harry E. White of Honolulu, complained that military surplus had been withdrawn from sale to go to "communistic" Korea and Yugoslavia. They also claimed that an official surplus property delegation from Korea was in Honolulu and that Korea had a $\$ 150$ million surplus property credit that meant that surplus would be withdrawn from sale to civilians until the credit had been met. WAA denied all of these allegations. ${ }^{40}$

White also cabled his complaint to Joseph Farrington, Hawai'i's delegate to Congress, as well as to Interior Secretary Krug and Drew Pearson, a nationally syndicated newspaper columnist. Farrington referred the complaint to UNRRA for a response. Lowell Rooks, director general of UNRRA, replied to Farrington that UNRRA was not providing any surplus to Korea. He confirmed that some tractors had been obtained in Hawai'i and sent to Yugoslavia and other countries. ${ }^{41}$

Allegations that surplus aircraft and spare parts were being sold to Russia brought a three-man investigatory team to Honolulu in March 1947. Headed by Edwin Donahue, chief counsel for the congressional committee investigating surplus property (known as the Rizley Committee), the team ultimately found no evidence to support the allegations. ${ }^{42}$

There were also charges that veterans served as fronts for surplus dealers and used their priorities to allow dealers to circumvent the priority system. Although these claims were often difficult to prove, a few dealers were suspended by SPO or WAA and a handful of individuals were prosecuted. In one case, Tom Rush, a representative of Sutton-Mort Co. and National Tractor Co., was convicted of fraud 
because he used local veterans as a front to buy $\$_{3} 6$,ooo worth of surplus in November 1946. ${ }^{43}$ In another case, federal judge Delbert Metzger fined Morris P. Woolley, a Honolulu contractor, for violating surplus laws. Woolley pleaded no contest to purchasing six C-47 transport planes from WAA. The planes had been purchased by veterans using their priorities, then turned over to the Hughes Tool Co. by Woolley, who acted as middleman. ${ }^{44}$

Honolulu was a popular destination for SPO and WAA administrators on inspection tours. One of the first officials to visit was P. H. Keppel of SPO's Washington office, who arrived in October $1945 \cdot{ }^{45}$ Major General Norman D. Cota, in charge of disposal of surplus in U.S. territories and possessions for WAA, visited in August 1947 accompanied by future WAA regional director Colonel Stanley G. Backman and three other officials. ${ }^{46}$ In April 1948, Rear Admiral Paul S. Mather, Associate Administrator of WAA, arrived in Honolulu on a "routine inspection tour." 47

\section{WAA Wraps UP in HoNOLUlu}

In September 1946 Governor Stainback requested that SPO vacate 'Iolani Palace, and the office began operating out of several temporary warehouses leased from the Navy at Kewalo Base Yard. ${ }^{48}$ After Cobb left, the regional office of WAA was headed by a succession of temporary directors from the Mainland. First to arrive was Palmer, who was appointed specifically to reorganize the operation of SPO to fit WAA's way of doing things. He expressed incredulity at the cumbersome policies and procedures under which SPO operated the same policies about which Cobb had bitterly complained) and vowed to streamline operations and hire additional personnel to speed disposal. Palmer brought a team of advisers from the Mainland to review all of the Honolulu office's operations and make recommendations for greater efficiency. ${ }^{49}$ They discovered that prices set for surplus in the Territory were generally higher than on the Mainland. Palmer developed new pricing policies that better reflected the likelihood that most surplus would be exported. ${ }^{50}$

By April 1947, all of the surplus remaining on Hawai'i Island, Moloka'i, and Kaua'i had been disposed of, and sales were being wrapped up on Maui. Writing in May 1947, John Gibbs, Information 
officer at WAA, enumerated many of the obstacles to the disposal of surplus property. He pointed to the laws and regulations themselves being the primary impediment. In addition, he noted that material was withdrawn from sale to be set aside for tsunami relief in Hawai'i and typhoon relief in Guam. Later, during the West Coast shipping strike of 1946 , the ability to ship goods to the Mainland was uncertain, which resulted in some Mainland buyers hesitating to purchase surplus goods. Surplus food was set aside to cover food shortages during the strike, but by the time the Territorial Board of Health had certified its fitness for consumption, the strike was over. Gibbs pessimistically observed, "The simple truth is that the government is not going to sell anything like 1 oo percent of its surplus, maybe not even 75 percent-not ever going to sell it, now or in the distant future." 51

In June 1947, WAA moved its operations to former WAAC barracks at Fort Ruger, where it occupied five buildings along the main road between the Kaimukī and Kahala gates. ${ }^{52}$ By late 1947, SPO was under enormous pressure to complete its work. WAA, desiring to attract more Mainland dealers, began to advertise Hawai'i sales on the Mainland. ${ }^{53}$ News articles reported that 37 sales of surplus property valued at $\$ 5^{\circ}$ million would take place in November 1947 , with additional sales planned for December and January. ${ }^{54}$ Notably, a sale of 1,700 vehicles began in September 1947 at Kipapa Air Field and continued through that October. Veterans had to go to Ft. Ruger to draw lots to determine their place in line. According to a news report, "The road from Kipapa back to Honolulu has been jammed with surplus vehicles, proud ex-GIs at the wheels, some of them being towed, but most proceeding under their own power." 55

Palmer was transferred to the San Francisco regional office of WAA in August 1947. ${ }^{56}$ His successor, Stanley G. Backman, arrived in September 1947. Backman, a retired Army colonel, had previously worked for WAA in Washington, Chicago, and Cleveland. He presided over several large sales of surplus that took place in fall 1947 . These concentrated sales were intended to be an improvement over the piecemeal approach used in the past, where many small sales took place at a variety of locations. ${ }^{57}$ However, Backman did not last long in Honolulu. Citing the need to return to the Mainland on account of his wife's health, he left in May 1948 for a temporary assignment 
to the San Francisco office of WAA. His replacement, Raub Snyder, was another experienced WAA hand who had served in the Kansas City office. Prior to that, he had been deputy director of UNRRA in China. ${ }^{58}$ Snyder was transferred back to the Mainland in August 1948. His replacement, Glen S. Taylor from the San Francisco WAA office, was the final director of the Honolulu office and oversaw the last of the WAA sales in the Territory. ${ }^{59}$

A November 1947 report by WAA stated that the cost of disposal exceeded the value of sales and suggested that dumping should be considered.$^{60}$ However, dumping of surplus would have created a public relations nightmare, so sales continued in 1948. WAA reported that it had reached an agreement with the armed services to suspend their surplus declarations through June so that WAA could clear out its inventories. ${ }^{61}$

WAA ended its sales operations in Honolulu in October 1948. Taylor reported that the government had realized about 20 percent of the value of goods through its sales. The office took in $\$ 6$ for each $\$ 1$ it spent on operations. ${ }^{62}$ The agency handled $\$ 400$, ooo, ooo worth of surplus during its existence. Fifty employees continued working until December $3^{1}$ to close out the books and finalize collections from Mainland buyers. After the closure of the office on December 31 , 1948, Edwin Kawahara of National Mortgage \& Finance Co. handled the remaining unfinished business through April 1949. ${ }^{63}$ In spite of all of the controversies, complaints, scandals, and investigations that had surrounded surplus disposal, a Honolulu Advertiser editorial praised WAA for a job well done. ${ }^{64}$

Although WAA ceased operations in Hawai'i 1948, sales of surplus real property (largely buildings) continued under the management of the Army and Navy through 1949 and 1950. In addition to selling real property, the Army and Navy also returned leased property to owners once they had determined that the property was no longer needed by the military. A Honolulu Advertiser article from March 1947 recapped the situation as it then stood. The Army held 210 ,ooo acres on V-J Day, of which 75 percent had been returned by $1947 \cdot 4,5$ oo acres were sugar cane land and 1,6oo acres were pineapple land. The Army still retained 65 ,ooo acres of land, of which 30 ,ooo acres was on O'ahu. The Navy held 9o,ooo acres of civilian land at the peak of the war, most of which had been returned by 1947 . The Navy also owned 
27,000 acres of fee simple land in the Territory, which it used for ammunition dumps, radio stations, and naval bases. ${ }^{65}$

Some of the land used by the military was former agricultural land. In some cases, these parcels were returned to their former use, but in other cases they stayed under military control. In November 1949, the Army announced that the final 270 acres of an 870-acre tract at Kipapa used by the Army and Air Corps has been returned to its civilian owners. After the war ended, the air field was closed, but the property was used to store surplus vehicles. The runways were eventually destroyed and returned to agricultural use. ${ }^{66}$

Many city parks and both public and private schools were also used by the armed forces for housing, baseyards, hospitals, canteens, and camps. ${ }^{67}$ All of these properties had to be reviewed to determine whether they were still needed for military purposes, then they had to be cleared of buildings and equipment prior to being returned to the Territory or the county.

Most of the disposal of surplus had concluded by $195^{\circ}$, although a small amount of surplus disposal continued after that point. Businesses that had sprung up or expanded to engage in surplus sales redirected their focus, veterans moved on to other jobs, and the armed forces turned their attention to the requirements of the Cold War.

People who worked in the war surplus industry transitioned to other careers and some attained prominent positions in government and industry. Perhaps the most famous local surplus dealer, future Honolulu mayor Frank Fasi, financed his early political campaigns through the proceeds from his surplus business. Other former surplus dealers such as Kilgo's Hardware and Tajiri Building Supplies enjoyed success in the post-surplus economy and some are still in operation.

Unlike many of the SPO staff members who came from the Mainland, served a short time, then left, William Cobb remained in Honolulu, where he worked for Surplus Sales Stores of Honolulu, Ltd. and then Universal Airplane Salvage Corp. as general manager of the company's Hawai'i operation. Cobb went on to open a law practice with Bernard Levinson, his former colleague at SPO, in 1949. In 1950, he unsuccessfully challenged Joseph Farrington in the election for Hawai'i's delegate to Congress. He also served as state coordinator of disaster relief in the 1940s-1950s and later 
became a bankruptcy judge. ${ }^{68,69}$ Bernard Levinson became a prominent leader in the local Jewish community and went on to serve as a circuit court judge and Hawai'i supreme court justice. ${ }^{70}$ Spark Matsunaga obtained a law degree from Harvard, served in the Territorial Legislature, and was elected to the U.S. House of Representatives and U.S. Senate. ${ }^{71}$

Today, remnants of World War II military surplus are still visible, from Quonset huts to Army jeeps to ammunition boxes. They serve as reminders of a time when stockpiles of surplus blanketed the Hawaiian Islands and surplus sales were part of the daily concerns of government agencies, the public, and the news media.

\section{Notes}

${ }^{1}$ Gerry Burtnett, "Disposal of U.S. Surplus Property Here Is Big Issue," HA Aug. $5,1945,1,9$.

2 Surplus Property Act of 1944, United States Statutes at Large, $5^{8}$ Stat. 765 , ch. 479, $1944,765-784$.

3 "Group to Ask Inspection of Salvage Piles," HA Dec. 1, 1945, 1.

${ }^{4}$ United States. Congress. House of Representatives. Select Committee to Investigate Disposition of Surplus Property, Investigation, Disposition of Surplus Property: Hearings Before the Select Committee to Investigate Disposition of Surplus Property, House of Representatives, Seventy-ninth Congress, Second Session, on H.Res. 385, a Resolution Relating to Disposition of Surplus Property. (Washington, D.C.: U.S. G.P.O., 1947).

5 "New Surplus Property Boss, Ex-Colonel, Takes Over Job," HA Dec. 18, $1945,1$.

${ }^{6}$ United States. Congress. Senate. Special Committee Investigating the National Defense Program, Surplus Property (Washington, D.C.: U.S. G.P.O., 1945).

7 Gerry Burtnett, "Surplus Charges in Ryan Report Denied to Solons," HA Jan. $3,1946,4$.

${ }^{8}$ United States. Congress. Senate. Special Committee Investigating the National Defense Program, Investigation of the National Defense Program, pt. 36 (Washington, D.C.: U.S. G.P.O., 1946): 19684 .

${ }^{9}$ Spec. Comm. Investigating the National Defense Program, Investigation of the National Defense Program.

${ }^{10}$ Gerry Burtnett, "Navy Releases Huge Lumber Surplus Here," HA Feb. 19, 1946, 1 .

11 "Kamuela Marine Base for Sale; Army Asks Bid," HA Mar. 2, 1946, 3 .

12 "WAVES Evacuate Village; Huts Go to Navy Families," HA Mar. 19, 1946, 2.

${ }^{13}$ Gerald Kinro, A Cup of Aloha: the Kona Coffee Epic (Honolulu: University of Hawai'i Press, 2003).

${ }^{14}$ Peter N. Forman, Wings of Paradise: Hawaii's Incomparable Airlines (Honolulu: Barnstormer Books, 2005). 
15 "Three Churches Bid for Surplus Army Chapel," HSB Dec. 25, 1948, 5 .

16 "HHA Advised on Procedure to Get 1000 Quonset Huts," HSB Feb. 3, 1946, Hawaii Newspaper Agency, Microfiche. Hamilton Library, University of Hawai' $i$ at Mānoa. Clippings Morgue.

17 "Kahului Airport Land, Buildings Parceled Out," HSB Feb. 4, 1948, 12.

18 "Army to Sell 2,50o Buildings," HSB July 19, 1947, 4.

19 “Territory Gets Buildings from Puunene Field," HA Oct. 28, 1948, 3.

20 "A Quonset Home," Hawaii Home (Feb. 1951): 2-5.

${ }^{21}$ Tonia Moi. The Kamaboko House. Dec. 28, 2013 Available from: http:// historichawaii.org/ 2013/12/28/the-kamaboko-house/.

22 "Wave Victims May Bid on Army Surplus," HSB June 10, 1946, 13.

${ }^{23}$ Buck Buchwach, "Planning to Buy Jeep? Keep That Purse Handy," HA June 10, 1946,1 .

${ }^{24}$ A. A. Smyser, "Easy Money in Surplus Material? Read This Before Buying Things," HSB Nov. 13, 1947, 11.

${ }^{25}$ George Woodbridge, UNRRA: The History of the United Nations Relief and Rehabilitation Administration (New York: Columbia University Press, 1950).

${ }^{26}$ Dewey T. Jones, History: The Hawaii (SURPROP) Mission, UNRRA, Monographs BS Pc 9, United Nations Archives and Records Management Section, New York, New York, 1947.

27 Woodbridge, UNRRA: The History.

28 Jones, The Hawaii (SURPROP) Mission.

${ }^{29}$ Jones, The Hawaii (SURPROP) Mission.

30 Millard S. Purdy, "UN To Spend Millions for Pacific Surplus" HA Mar. 6, 1946 , 1.

${ }^{31}$ Stuart M. Ball Jr., Native Paths to Volunteer Trails: Hiking and Trail Building on O‘ahu (Honolulu: University of Hawaii Press, 2012).

32 "Amphibious Training for Combat Army Mules," PP 57:4 (April 1945): 6-7.

${ }^{33}$ Buck Buchwach, "Old Mules Never Die, 'They Just Fade Away to China'," HA Ap. 26, 1946 .

${ }^{34}$ William M. Leary, Perilous Missions: Civil Air Transport and CIA Covert Operations in Asia (University of Alabama Press, 1984).

35 “Meddling in Capital Blasted; 'Clique' Charges Laid By Surplus Property Employees," HSB Feb. 4, 1947, 1.

36 "Captain from 1ooth to Advise Vets on Surplus Purchases," HA Dec. 9, 1945, 5.

37 "Cobb Quits as Surplus Chief, Blasts Washington," HA Feb. 21, 1947, 1.

38 "Isle Surplus Needs Studied; Excess Will Go to Mainland," HA Mar. 29, 1946, 3.

39 "Discrimination in Surplus Property Order Is Rapped," HA Ap. 9, 1946, 4.

40 "Large Shipments of Surplus Will Go to Korea from Here," HSB Jun. 20, 1947, 1,6 .

${ }^{41}$ Lowell D. Rooks, Letter to Joseph R. Farrington, 1947, UNRRA, S-1302-0ooo-4481, United Nations Archives and Records Management, New York, New York.

42 "Surplus Deals Here Probed for Sales to Russ," HA Mar. 27, 1948, 1.

43 "Rush Fined $\$ 10,000$ in Surplus Fraud Case; Veteran Employed as "Front"; Three Indictments on Similar Charges are Dismissed," HSB Dec. 17, 1947, 1. 
44 “\$10,000 Fine in Surplus Plane Deal; Contractor Is Third Assessed in WAA Case," HA Oct. 8, 1949, 9 .

45 "Levinson Here as Legal Adviser in Property Office," HSB Oct. 1, 1945, Hawaii Newspaper Agency, Microfiche. Hamilton Library, University of Hawai'i at Mānoa. Clippings Morgue.

46 "Gen. Cota Due Here Today “ HA Aug. 7, 1947, 5.

47 "Raub Snyder Named New War Assets Director Here," HSB Apr. 13, 1948, Hawaii Newspaper Agency, Microfiche. Hamilton Library, University of Hawai 'i at Mānoa. Clippings Morgue.

${ }^{48}$ John T. Gibbs, Sale of War Surplus Property in the Territory of Hawaii, 1947, Hawaii War Records Depository, File 29, Archives \& Manuscripts Department, University of Hawai'i at Mānoa Library.

49 "WAA Chief Sending for Help from Washington," HSB Feb. 27, 1947, Hawaii Newspaper Agency, Microfiche. Hamilton Library, University of Hawai'i at Mānoa. Clippings Morgue.

50 “Chamber Group Favors Palmer Policy Setup," HSB Ap. 20, 1947, Hawaii Newspaper Agency, Microfiche. Hamilton Library, University of Hawai'i at Mānoa. Clippings Morgue.

${ }^{51}$ Gibbs, Sale of War Surplus Property.

52 "WAA Offices Here Moving to Fort Ruger," HA June 29, 1947, 12.

53 “TH Surplus Disposal to be Speeded," HA Sep. 22, $1947,1$.

54 "Huge Surplus Offer Planned," HA Nov. 1, 1947, 6.

55 "Vets Snap Up Surplus Cars," HA Oct. 1, 1947, 7.

56 "Palmer Ends Reorganizing of WAA Here," HSB Aug. 20, 1947, Hawaii Newspaper Agency, Microfiche. Hamilton Library, University of Hawai'i at Mānoa. Clippings Morgue.

57 "Backman Here as WAA Head," HSB Sep. 10, 1947, Hawaii Newspaper Agency, Microfiche. Hamilton Library, University of Hawai'i at Mānoa. Clippings Morgue.

58 "Raub Snyder Named New War Assets Director Here," HSB Ap. 13, 1948, Hawaii Newspaper Agency, Microfiche. Hamilton Library, University of Hawai ' 1 at Mānoa. Clippings Morgue.

59 “New Director of WAA Plans Quick Sellout," HSB Aug. 22, 1948, 13.

60 “T.H. Surplus Sale Drop Is Reported," HA Nov. 2 1, $1947,1$.

61 “\$75,000,ooo In Surplus Property to Be Sold Here," HA Feb. 29, 1948, 1.

62 "WAA Will Close Here at End of Year," HSB Nov. 5, 1948, 18.

63 "WAA Office in Honolulu to Close Friday," HA Dec. 29, 1948, 1.

64 "WAA Does a Big Job Well," HA Jan. 4, 1949, Ed.

65 "Services Return Land in T.H., Chiefs Tell Council," HA Mar. 4, 1947, 6.

66 “Army Gives Up Kipapa Lands," HA Nov. 9, 1949, 11.

${ }^{67}$ Gwenfread Allen, Hawaii's War Years, I94I-1945 (Honolulu: University of Hawaii Press, 1950).

68 "Bankruptcy Court Judge Will Retire," HSB Feb. 6, 1976, Hawaii Newspaper 
Agency, Microfiche. Hamilton Library, University of Hawai'i at Mānoa. Clippings Morgue.

69 "Cobb Appointed Coordinator of Disaster Relief," HSB Mar. 8, 1950, Hawaii Newspaper Agency, Microfiche. Hamilton Library, University of Hawai'i at Mānoa. Clippings Morgue.

70 "Bernard H. Levinson, Former Justice, Dies," HSB Mar. 14, 1979, Hawaii Newspaper Agency, Microfiche. Hamilton Library, University of Hawai'i at Mānoa. Clippings Morgue.

${ }^{71}$ University of Hawai'i at Mānoa Library, Finding Aid, 2005, Senator Spark M. Matsunaga Papers, University of Hawai'i at Mānoa Library. 